\title{
TURMERIC EXTRACT POTENTIAL INHIBIT INFLAMMATORY MARKER IN LPS-STIMULATED MARCOPHAGE CELLS
}

\author{
WAHYU WIDOWATI ${ }^{*}$, DIANA KRISANTI JASAPUTRA ${ }^{1}$, KAMILA YASHFA GUNAWAN ${ }^{2}$, HANNA SARI WIDYA \\ KUSUMA $^{2}$, SEILA ARUMWARDANA ${ }^{2}$, CINTANI DEWI WAHYUNI ${ }^{2}$, I. NYOMAN EHRICH LISTER ${ }^{3}$, CHRISMIS \\ NOVALINDA GINTING ${ }^{3}$, ERMI GIRSANG ${ }^{3}$, RIZAL RIZAL ${ }^{2,4}$
}

\begin{abstract}
${ }^{1}$ Faculty of Medicine, Maranatha Christian University, Bandung 40163, West Java, Indonesia, ${ }^{2}$ Aretha Medika Utama, Biomolecular Research Center, Bandung 40163, West Java, Indonesia, ${ }^{3}$ Faculty of Medicine, Universitas Prima Indonesia, Medan 20118, North Sumatera, Indonesia, ${ }^{4}$ Biomedical Engineering, Department of Electrical Engineering, Faculty of Engineering, Universitas Indonesia, Depok 16426, West Java, Indonesia Email: wahyu_w60@yahoo.com
\end{abstract}

Received: 10 Aug 2020, Revised and Accepted: 04 Oct 2020

\begin{abstract}
Objective: Inflammation can be induced by microbiological, chemical, physical factors and plays roles in inflammatory diseases. Turmeric (Curcuma longa L.) has been widely used to provide a diverse array of biological activities, including anti-inflammatory, antimicrobial, also antioxidant. The Turmeric extract (TE) anti-inflammatory potential was conducted using a Lipopolysaccharide (LPS)-induced RAW264.7 macrophage cell line by inhibiting inflammatory mediators especially IL-6, PGE-2, IL-1 $\beta$, COX-2, TNF- $\alpha$, iNOS, also NO level.

Methods: The TE safe concentration in LPS-induced macrophage cell line was measured using MTS assay for further assay. The inflammatory markers (IL-6, PGE-2, COX-2, IL-1 $\beta$, TNF- $\alpha$, iNOS, NO) were measured using ELISA assay and NO by the nitrate/nitrite colorimetric assay in LPSinduced RAW264.7 cell line. LPS induced inflammatory marker by increasing inflammatory marker (IL-6, PGE-2, COX-2, IL-1 $\beta$, TNF- $\alpha$, iNOS, NO).

Results: TE with 100 to $25 \mu \mathrm{g} / \mathrm{ml}$, caused a significant reduction of cells viability, reaching only $30.27 \%$ live cells. TE with lower concentrations $(7.5 ; 5 ; 2.5 \mu \mathrm{g} / \mathrm{ml}$ ) had no cytotoxic effect on macrophage cells (viability 117.31-131.08\%). LPS induction caused an increase in inflammatory cytokines IL-1 $\beta$, PGE-2, IL-6, COX-2, TNF- $\alpha$ as well as iNOS and NO. Turmeric extract caused the reduction of the inflammatory cytokines in a dosedependent manner.
\end{abstract}

Conclusion: The research resulted that TE has anti-inflammatory activity by decreasing IL-6, PGE-2, COX-2, IL-1 $\beta$, TNF- $\alpha$, iNOS, and NO level on LPS-induced RAW264.7 cells.

Keywords: Inflammation, Turmeric, TNF $\alpha$, IL-6, IL-1 $\beta$

(C) 2021 The Authors. Published by Innovare Academic Sciences Pvt Ltd. This is an open access article under the CC BYlicense (https://creativecommons.org/licenses/by/4.0/) DOI: https://dx.doi.org/10.22159/ijap.2021.v13s3.01 Journal homepage: https://innovareacademics.in/journals/index.php/ijap

\section{INTRODUCTION}

Inflammation is the host natural defence against pathogen infections, which also can be induced by microbiological, chemical, physical factors [1-3]. Inflammation involves several events such as changes in blood flows and vascular permeability, activation and migrations of leukocytes, and synthesis of local inflammatory mediators. The inflammatory mediators such as interleukin (IL)-1 $\beta$, prostaglandin E2 (PGE2), IL-6, tumor necrosis factor-alpha (TNF- $\alpha$ ), cyclooxygenase-2 (COX-2), and nitric oxide (NO) has been observed as the primary response to inflammation [4, 5]. Prolonged exposure to these inflammatory mediators may induce acute and/or chronic inflammatory responses in the organs such as heart, lung, brain, and reproductive systems and potentially leading to tissues damage $[4,6$, 7]. Increased level of TNF- $\alpha$ elicited platelet activation when during inflammation the complement is activated on the surface of platelet $[8,9]$ meanwhile burst of IL- $1 \beta$ are involved in acute attack of systemic or local inflammation [10] and IL-6 trans signal mediate inflammation from acute to chronic [11]. To treat the inflammatory related disease, abundance research has been conducted to find potential anti-inflammatory compounds, including plants-derived compounds. Turmeric (Curcuma longa L) has been used as traditional therapy over the years, including in the ayuverdic medication. Turmeric has been provided scientifically against such human ailments [12]. Turmeric contains active compounds, classified as curcuminoids, consist of curcumin (77\%), bisdemethoxycurcumin (3\%) and demethoxycurcumin (17\%). Curcumin has been stated as major biologically active components having anti-bacterial, anti-diabetic, anti-oxidant, anti-inflammatory activities, lowering cholesterol [13].

The widely used as inflammatory cells model in vitro was murine macrophage cell line (RAW 264.7). While lipopolysaccharide (LPS) as bacterial metabolite is one of the well-studied stimulus to induce inflammatory mediators' secretion. In the current study, we focused on the turmeric extract (TE) potential anti-inflammatory activity by modulating the pro-inflammatory molecules production (TNF- $\alpha$, PGE-2, IL-1 $\beta$, iNOS, IL-6, COX-2, and NO).

\section{MATERIALS AND METHODS}

\section{Materials}

Turmeric (C. longa L.) rhizome was collected from farmer plantation in Bogor, West Java, Indonesia. The murine macrophage cell line (RAW 264.7, ATCC TIB-71) was obtained from Biomolecular and Biomedical Research Center, Aretha Medika Utama, Bandung, Indonesia. Dulbecco's Modified Eagle Medium (DMEM) (from Biowest, L0104), 10\% fetal bovine serum (FBS) (from Biowest, S1810-500), 1\% Antibiotic/ antimycotic (ABAM, from Biowest, L0010-100), 1\% Nanomycopulitine (from Biowest, L-X16-010), and 0.1\% Gentamicin (from Gibco 15750078). Bovine Standard Albumin (BSA) (from Sigma Aldrich, A9576). Quick Start Dye Reagent 1X (from Biorad, 5000205). LPS from Escherichia coli (Sigma Aldrich, L2880), MTS (3-(4,5-dimethylthiazol-2yl)-5-(3-carboxymethoxy-phenyl)-2-(4-sulfophenyl)-2H-tetrazolium) (from Abcam, ab197010), Elisa Kit mouse IL-1ß (E-EL-M0037), mouse TNF- $\alpha$ (E-EL-M0049), mouse COX-2 (E-EL-M0959), mouse IL-6 (E-ELM0044), PGE-2 (E-EL-0034), mouse iNOS (E-EL-M0696), NO Colorimetric Assay (E-BC-K035-M).

\section{Methods}

\section{Extraction process}

Turmeric (Curcuma longa L.) rhizome was identified by herbarium staff of Scholl of Life Sciences, Bandung Institute of Technology, 
Bandung, West Java, Indonesia. One kilogram of dried rhizome powder was macerated using distilled ethanol, filtered, and evaporated by rotary evaporator (Zhengzhou Well-known, RE201D). The turmeric extract (TE) in the form of paste was stored at$20{ }^{\circ} \mathrm{C}$ until further use [14].

\section{Cells culture}

Cells that used in this study (murine macrophage cell line also known as RAW 264.7) was cultured in DMEM, ABAM, FBS, Gentamicin, and Nanomycopulitine then incubated at $37{ }^{\circ} \mathrm{C}$ in a humidified atmosphere with $5 \% \mathrm{CO}_{2}$. When the cells was at $80 \%$ confluency, it was harvested using cells scrapper [15-18].

\section{Cells viability measurements}

MTS assay was used to measured murine macrophage cell line viability. In 96 well-plates, cells ( $5 \times 10^{3}$ cells/well) were planted in $180 \mu \mathrm{l}$ growth medium also extract with various concentrations $(100 ; 75 ; 50 ; 25 ; 7,5 ; 5 ; 2.5 ; 0 \mu \mathrm{g} / \mathrm{ml})$ as much as $20 \mu \mathrm{l}$, then incubated in $37{ }^{\circ} \mathrm{C}$ with $\mathrm{CO}_{2} 5 \%$ for $24 \mathrm{~h}$. Then the reagent (MTS) was added into each well and incubated at the same condition for 3 h. At the wavelength of $490 \mathrm{~nm}$ in a microplate reader (Multiskan Go, Thermo Scientific), the absorbance was read using and cells viability was calculated [10-14].

\section{LPS-induced RAW cells and treatments}

In 6 well plate, cells $\left(5 \times 10^{5}\right.$ cells/well) were planted and incubated for $24 \mathrm{~h}$. It was treated with TE and induced by LPS. Six treatments that used for this research: (1) the negative control (without induced by LPS); (2) positive control (induced by $1 \mu \mathrm{g} / \mathrm{ml}$ LPS); (3) macrophage cells that induced by $1 \mu \mathrm{g} / \mathrm{ml}$ LPS and treated by TE at $7.5 \mu \mathrm{g} / \mathrm{ml}$; (4) macrophage cells that induced by $1 \mu \mathrm{g} / \mathrm{ml}$ LPS and treatetd by TE at $5 \mu \mathrm{g} / \mathrm{ml}$; (5) macrophage cells that induced by $1 \mu \mathrm{g} / \mathrm{ml}$ LPS and treated by TE $2.5 \mu \mathrm{g} / \mathrm{ml}$. It was incubated for another $24 \mathrm{~h}$. After that, the conditioned medium was collected. It was centrifuged and collected the cell-free supernatant that used for measure the COX-2, IL$1 \beta$, TNF- $\alpha$, IL-6, PGE-2, iNOS, and NO level [15-19].

\section{Measurement of IL-1 $\beta$, TNF- $\alpha$, COX-2, IL-6, PGE-2, and iNOS level}

ElabScience Elisa Kit was used to measure the IL-1 $\beta$, TNF- $\alpha$, COX-2, IL-6, PGE-2, iNOS level used under manufacture protocols [15-22].

\section{Measurement of NO level}

The nitrite associated with NO production was measured using NO Colorimetric Assay that performed based on manufacture protocols. The Sodium Nitrite Standard curve was determined to measure the nitrite quantity [15-17].

\section{Statistical analysis}

SPSS software (IBM SPSS 22) were used to statistically analysed the data. The statistical significance among treatments was evaluated using One-way Analysis of Variance (ANOVA) followed by Tukey HSD post hoc test with $\mathrm{p}<0,05$.

\section{RESULTS AND DISCUSSION}

The cytotoxic effect of TE toward macrophage cells were done to determine the safe extract concentration. TE with 100 to $25 \mu \mathrm{g} / \mathrm{ml}$ caused a significant reduction of cells viability, reaching only 30.27 $\%$ live cells. The lower concentrations of TE $(2.5 ; 5 ; 7.5 \mu \mathrm{g} / \mathrm{ml})$ was showed no cytotoxic effect on macrophage cells (viability 117.31$131.08 \%$ ) (fig. 1).

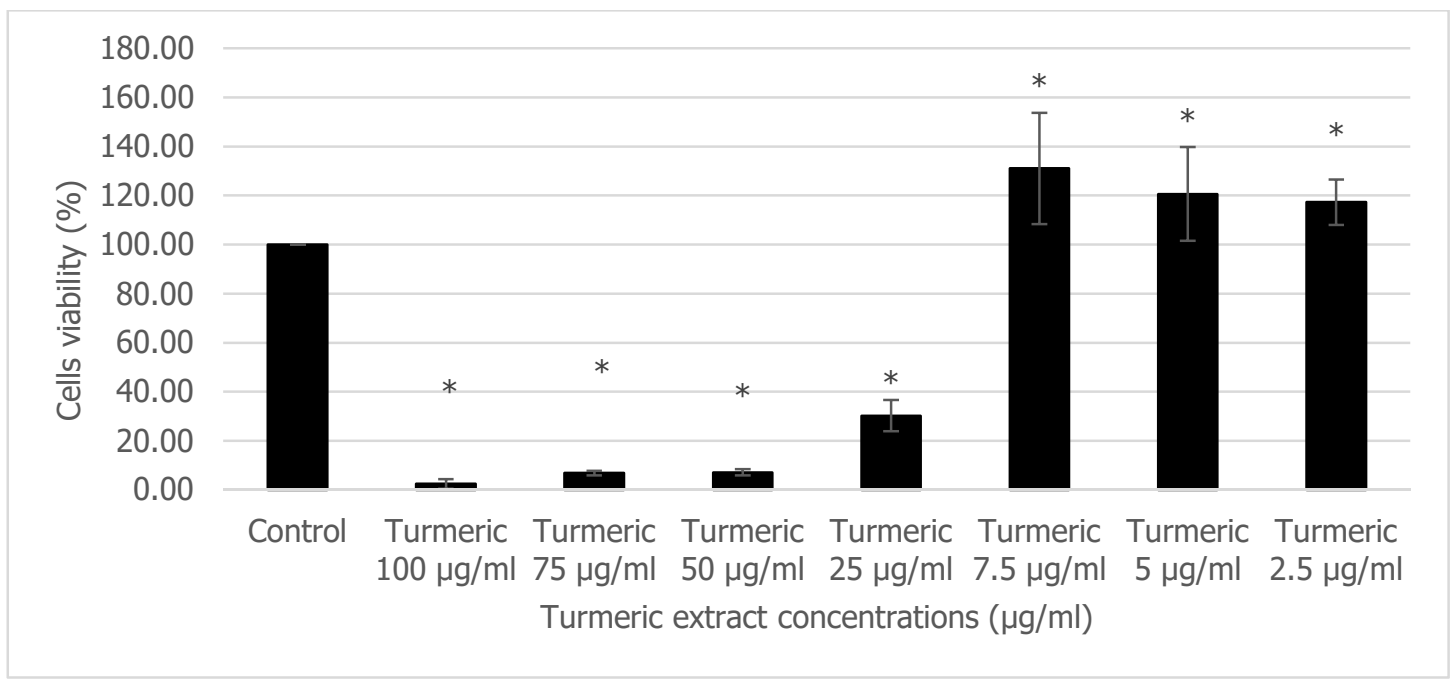

Fig. 1: Effect of turmeric extract on RAW 264.7 cells viability,

The data was presented as mean+standard deviation that has been analysed by using Tukey HSD post hoc test at p $<0.05$. Single asterisk ${ }^{*}$ ) shows significant differences compared to control.

LPS induction caused increase in inflammatory cytokines such as TNF- $\alpha$ (fig. 2a), IL-6 (fig. 2b), IL1- $\beta$ (fig. 2c), PGE-2 (fig. 2d), COX-2 (fig. 2e) as well as iNOS (fig. 2f) and NO (fig. 2g). TE reduced the inflammatory cytokines in dose-dependent manner. The main mechanism of TE action is by curcumin content which has been shown in various inflammatory models such as macrophage $[24,25$, $32]$, microglial cells $[26,28,29,31]$ induced by LPS, and macrophage cells induced by adipocyte conditioned medium from obesity patients $[27,30]$.

LPS induces macrophage activation through extracellular region of Toll-Like receptor 4 (TLR4) [33]. The activated TLR4 will activate cascades events in the cytoplasm which leads to MAPK (JNK, ERK1/2, p38) pathway activation. The phosphorylated MAPKs causes phosphorylation of inhibitory factor kappa B (IkB) which leads to nuclear factor-kappa B (NFkB) activation, followed by its translocation to the nucleus. NFKB is a ubiquitous transcription factor that controls genes expression involved in apoptosis, immune responses, and cell cycle [34].

Exposure LPS to cells leads the dimerization of NFkB which leads to inflammatory related genes activation such as IL-1 $\beta$, TNF- $\alpha$, PGE-2, IL-6, iNOS, also COX-2 $[35,36]$. TNF- $\alpha$ and IL-1 $\beta$ is the innate immune response mediator which leads to other inflammatory cytokines secretion. TNF- $\alpha$ induces leukocytes adhesion molecules expression, leading to diapedesis through vascular endothelial cells. IL-6 mainly acts in acute response and activation of lymphocytes' antibody secretion $[23,35,36]$ JNK signaling cascade regulates LPSstimulated iNOS expression [35]. Meanwhile iNOS is an enzyme that produces NO [5]. NO is synthesized and released into the endothelial cells and mediates vasodilatation which helps leukocytes migration to the site of infection [5]. 


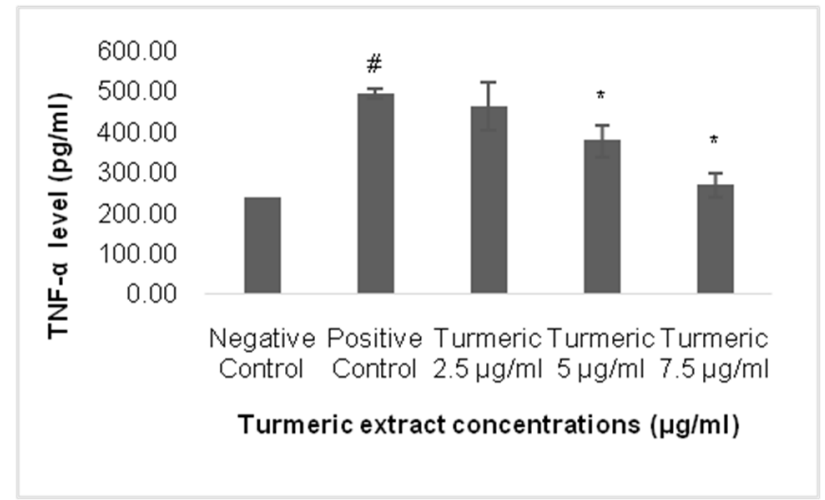

(a)

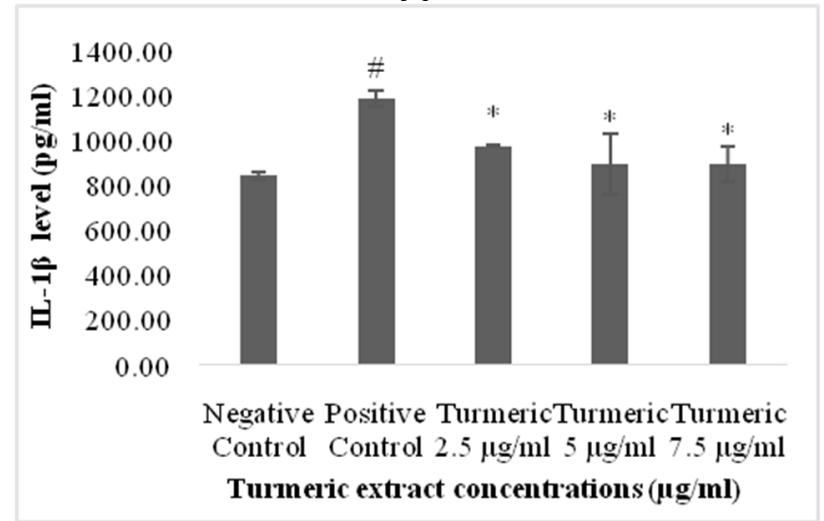

(c)

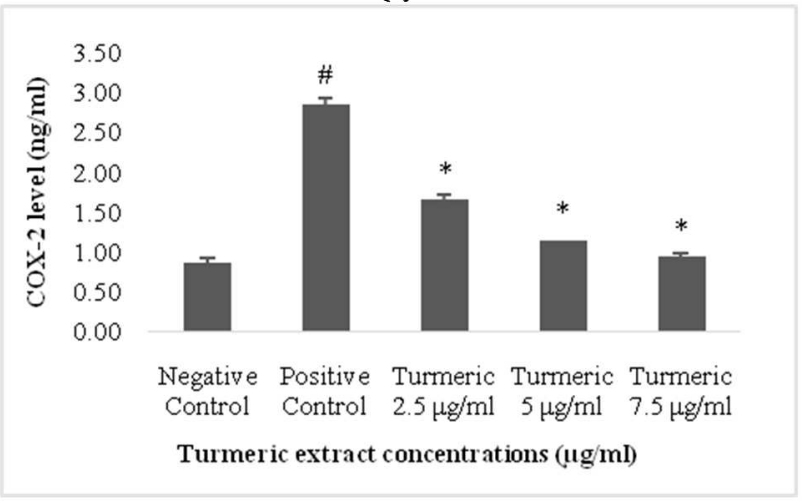

(e)

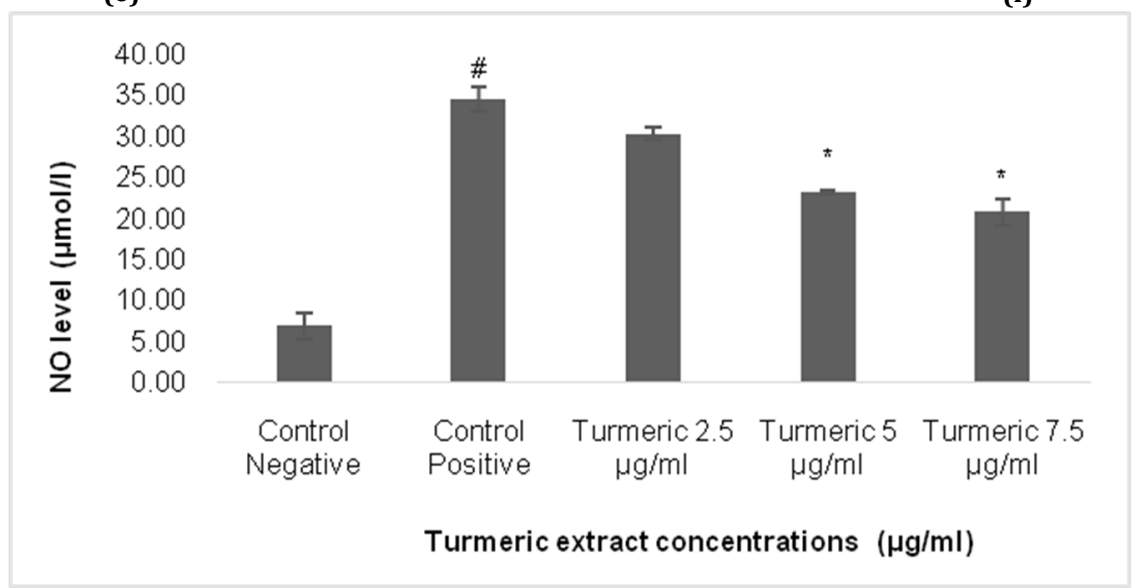

(g)

Fig. 2: Turmeric extract effect in LPS-stimulated macrophage cells toward inflammatory marker, data is presented as mean+standard deviation that has been analysed using Tukey HSD post hoc test $(p<0.05)$. Single asterisk symbol $(*)$ shows significant differences among treatment compared to positive control and hashtag symbol (\#) shows significant differences between positive control and negative control. All groups were conducted in triplicate. (a) TNF $\alpha$ level, (b) IL-6 level, (c) IL-1ß level, (d) PGE-2 level, (c) COX-2 level, (f) iNOS level, (g) NO level
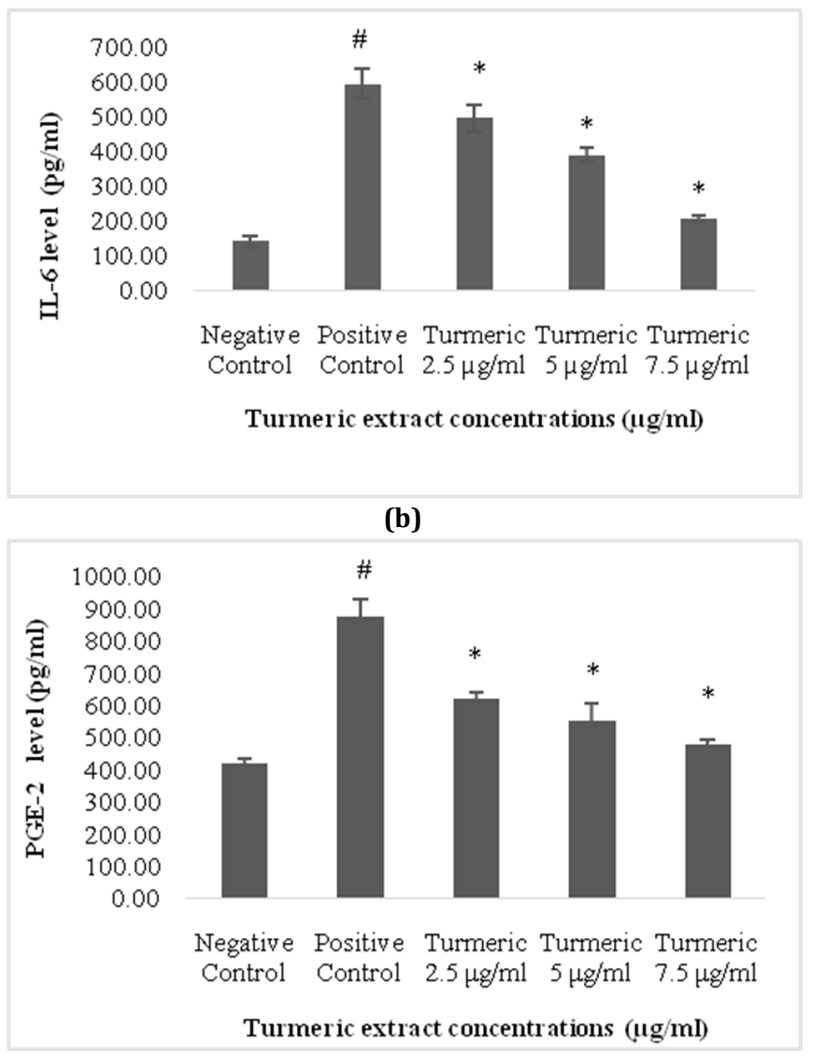

(d)

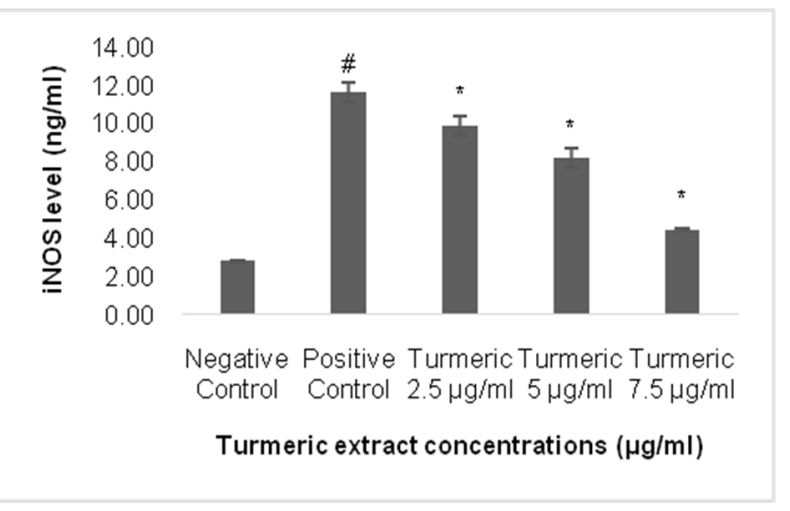

(f) 
Turmeric extract mainly acts through curcumin which has been widely studied and has been known to have anti-inflammatory properties through several molecules inhibition. Curcumin causes inhibition of inflammatory-related kinases such as JNK, ERK, MAPK, transcription factors such as NFKB, enzymes such as iNOS, as well as the inflammatory cytokines such as IL-6, TNF- $\alpha$, and IL-1 [37]. Our results suggest that TE could inhibit the LPS-induced inflammatory marker including NO, PGE-2, TNF- $\alpha$, IL-1 $\beta$, COX-2, IL1- $\beta$, IL-6, iNOS level. We proposed the mechanism of action anti-inflammatory property of TE based on our result and literature review in fig. 3 .

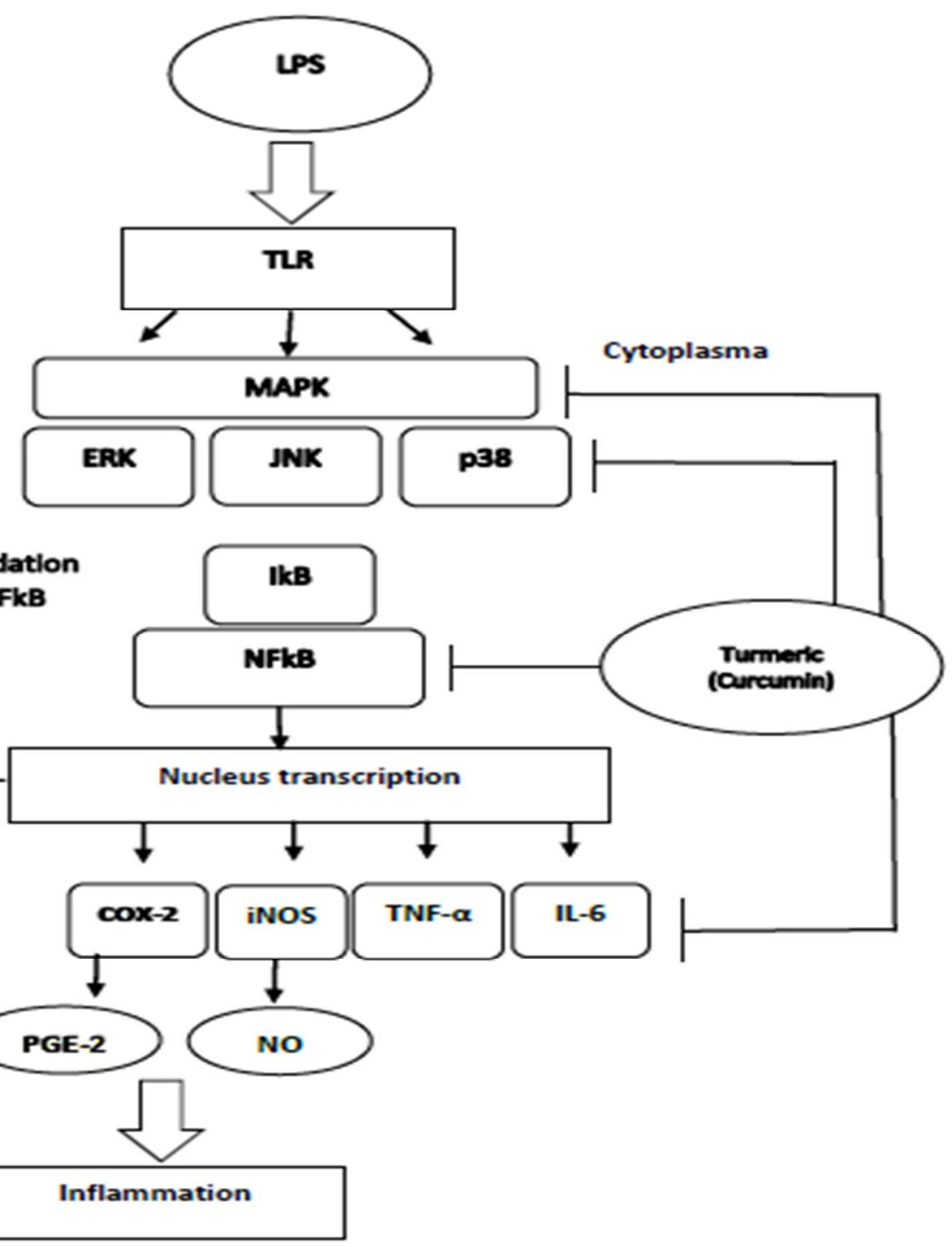

Fig. 3: Proposed mechanism of LPS-induced inflammation inhibition by turmeric extract

\section{CONCLUSION}

Turmeric extract has a potential as anti-inflammatory by decreasing TNF- $\alpha$, IL-6, PGE-2, COX-2, IL-1 $\beta$, NO and iNOS. While this research could be used as a reference for anti-inflammatory activity of turmeric in vitro research, further research by in vivo and clinical trial is needed for confirmation of the result.

\section{ACKNOWLEDGEMENT}

The authors gratefully acknowledge to Biomolecular and Biomedical Research Center, Aretha Medika Utama, Bandung, West Java, Indonesia for financial support, laboratory facilities and research method. We also thank to Aditya Rinaldy, Muhamad Aldi Maulana from Aretha Medika Utama Biomolecular and Biomedical Research Center for their valuable assistance.

\section{FUNDING}

\section{AUTHORS CONTRIBUTIONS}

All the authors have contributed equally.

\section{CONFLICTS OF INTERESTS}

There are no conflicts of interest.

\section{REFERENCES}

1. Jin R, Yang G, Li G. Inflammatory mechanisms in ischemic stroke: role of inflammatory cells. J Leukocyte Biol 2010;87:779-89.

2. Petersen AMW, Pedersen BK. The anti-inflammatory effect of exercise. J Appl Physiol 2005;98:1154-62.

3. Abrahamsen B, Zhou I, Asante CO, Cendan CM, Marsh S Martinez Barbera JP, et al. The cell and molecular basis of mechanical, cold, and inflammatory pain. Sci 2008;321:702-5.

4. Chen L, Deng H, Cui H, Fang J, Zuo Z, Deng J, et al. Inflammatory responses and inflammation-associated diseases in organs. Oncotarget 2017;9:7204-18. 
5. Sharma JN, Al-Omran A, Parvathy SS. Review role of nitric oxide in inflammatory disease. Inflammopharmacology 2007;15:2529.

6. Wu YS, Chen SN. Apoptotic cell: linkage of inflammation and wound healing. Front Pharmacol 2014;5:1-6.

7. Lam D, Harris D, Qin Z. Inflammatory mediator profiling reveals immune properties of chemotactic gradients and macrophage mediator production inhibition during thioglycollate elicited peritoneal inflammation. Mediators Inflamm 2013:1-9.

8. Manfredi AA, Baldini M, Camera M, Baldissera E, Brambilla M, Peretti G, et al. Anti-TNF $\alpha$ agents curb platelet activation in patients with rheumatoid arthritis. Annals Rheumatic Diseases 2016;75:1511-20.

9. Page MJ, Bester J, Pretorius E. The inflammatory effects of TNF$\alpha$ and complement component 3 on coagulation. Sci Reports 2018;8:1-9.

10. Dinarello CA. A clinical perspective of IL-1 $\beta$ as the gatekeeper of inflammation. Eur J Immunol 2011;41:1203-17.

11. Rose John S, Scheller J, Elson G, Jones SA. Interleukin-6 biology is coordinated by membrane-bound and soluble receptors: role in inflammation and cancer. J Leukoc Biol 2006;80:227-36.

12. Aggarwal BB, Yuan W, Li S, Gupta SC. Curcumin-free turmeric exhibits anti-inflammatory and anticancer activities: identification of novel components of turmeric. Mol Nutr Food Res 2013;57:1529-42.

13. Kocaadam B, Şanlier N. Curcumin, an active component of turmeric (Curcuma longa), and its effects on health. Crit Rev Food Sci Nutr 2017;57:2889-95.

14. Widowati W, Sardjono CT, Wijaya W, Laksmiwati DR, Darsono L. Free radicals scavenging of spices and curcumin. Proceedings of the Second International Syposium on Temulawak and the $40^{\text {th }}$ Meeting of National Working Group on Indonesian Medicinal Plant; 2011.

15. Widowati W, Darsono L, Suherman J, Fauziah N, Maesaroh M, Erawijantari PP. Anti-inflammatory effect of mangosteen (Garcinia mangostana L.) peel extract and its compounds in LPS-induced RAW264.7 cells. Nat Prod Sci 2016;22:147-53.

16. Laksmitawati DR, Widyastuti A, Karami N, Afifah E, Rihibiha DD, Nufus $\mathrm{H}$, et al. Anti-inflammatory effects of Anredera cordifolia and Piper crocatum extracts on lipopolysaccharidestimulated macrophage cell line. Bangladesh J Pharmacol 2017; 12:35-40.

17. Arina N, Djamhuri DS, Nurhayati B, Rihibiha DD, Afifah E, Widowati W. Anti-inflammatory properties of oolong tea (Camellia sinensis) ethanol extract and epigallocatechin gallate in LPS-induced RAW 264.7 cells. Asian Pacific J Tropic Biomed 2017;7:1005-9.

18. Sandhiutami NMD, Moordiani M, Laksmiwati DR, Fauziah N, Maesaroh M, Widowati W. In vitro assesment of antiinflammatory activities of coumarin and Indonesian cassia extract in RAW 264.7 murine macrophage cell line. Iran J Basic Med Sci 2017;20:99-106.

19. Widowati W, Prahastuti S, Ekayanti NLW, Munshy UZ, Kusuma HSW, Wibowo SHB, et al. Anti-Inflammation assay of black soybean extract and its compounds on lipopolysaccharideinduced RAW 264.7 cell. J Physics: Conference Series 2019;1374:1-11.

20. Pluemsamran T, Onkoksoong T, Panich U. Caffeic acid and ferulic acid inhibit UVA-induced matrix metalloproteinase- 1 through regulation of antioxidant defense system in keratinocyte HaCaT cells. Photochem Photobiol 2012;88:961-8.
21. Singh N, Sundar S. Inflammatory chemokines and their receptors in human visceral leishmaniasis: gene expression profile in peripheral blood, splenic cellular sources and their impact on trafficking of inflammatory cells. Mol Immunol 2017;85:111-9.

22. Mahajna S, Azab M, Zaid H, Farich BA, Al Battah FF, Mashner S, et al. In vitro evaluations of cytotoxicity and antiinflammatory effects of Peganum harmala seed extracts in THP-1-derived macrophages. Eur J Med Plants 2015;5:165-75.

23. Bruderer M, Alini M, Stoddart M. Role of HOXA9 and VEZF1 in endothelial biology. J Vasc Res 2013;50:265-78.

24. Zhao C, Yang J, Wang Y, Liang D, Yang X, Li X, et al. Synthesis of mono-carbonyl analogues of curcumin and their effects on inhibition of cytokine release in LPS-stimulated RAW 264.7 macrophages. Bioorg Med Chem 2010;18:2388-93.

25. Aggarwal BB, Gupta SC, Sung B. Curcumin: an orally bioavailable blocker of TNF and other pro-inflammatory biomarkers. Br J Pharmacol 2013;169:1672-92.

26. Zhang QY, Mo ZN, Liu XD. Reducing effect of curcumin on expressions of TNF-alpha, IL-6 and IL-8 in rats with chronic nonbacterial prostatitis. Zhonghua Nan Ke Xue 2010;16:84-8.

27. Woo HM, Kang JH, Kawada T, Yoo H, Sung MK, Yu R. Active spice-derived components can inhibit inflammatory responses of adipose tissue in obesity by supressing inflammatory actions of macrophages and release of monocyte chemoattractant protein-1 from adipocytes. Life Sci 2007;80:926-31.

28. Jin CY, Lee JD, Park C, Choi YH, Kim GY. Curcumin attenuates the release of pro-inflammatory cytokines in lipopolysaccharide-stimulated BV2 microglia. Acta Pharmacol Sin 2007;28:1645-51.

29. Lee HS, Jung KK, Cho JY, Rhee MH, Hong S, Kwon M, et al. Neuroprotective effect of curcumin is mainly mediated by blockade of microglial cell activation. Pharmazie 2007;62:937-42.

30. Wang SL, Li Y, Wen Y, Chen YF, Na LX, Li ST, et al. Curcumin, a potential inhibitor of up-regulation of TNF-alpha and IL-6 induced by palmitate in 3T3-L1 adipocytes through NF-kappa B and JNK pathway. Biomed Environ Sci 2009;22:32-9.

31. Zhang L, Wu C, Zhao S, Yuan D, Lian G, Wang X, et al. Demethoxycurcumin, a natural derivative of curcumin attenuates LPS-induced pro-inflammatory responses through down-regulation of intracellular ROS-related MAPK/NF-kappa $\mathrm{B}$ signaling pathways in N9 microglia induced by lipopolysaccharide. Int Immunopharmacol 2010;10:331-8.

32. Liang G, Li X, Chen L, Yang S, Wu X, Studer E, et al. Synthesis and anti-inflammatory activities of mono-carbonyl analogues of curcumin. Bioorg Med Chem Lett 2008;18:1525-9.

33. Mosser DM, Edwards JP. Exploring the full spectrum of macrophage activation. Nat Rev Immunol 2008;8:958-69.

34. Ledoux AC, Perkins ND. NF-kB and the cell cycle. Biochem Soc Trans 2014;42:76-81.

35. Lee CW, Kim SC, Kwak TW, Lee JR, Jo MJ, Ahn YT, et al. Antiinflammatory effects of bangpungtongsung-San a traditional herbal prescription. Evidence-Based Complement Altern Med 2012;892943:1-12.

36. Alam Md B, Ju MK, Kwon YG, Lee SH. Protopine attenuates inflammation stimulated by carrageenan and LPS via the MAPK/NF-kB pathway. Food Chem Toxicol 2019;131:110583.

37. Kunnumakkara AB, Bordoloi D, Padmavathi G, Monisha J, Roy NK, Prasad S, et al. Curcumin, the golden nutraceutical: multitargeting for multiple chronic diseases. Br J Pharmacol 2017;174:1325-48. 